\title{
The Personality Profile of Normal and Psychopaths of Hills and Plains: A Clinical Analysis
}

\author{
Rupali Chandola ${ }^{1} *$
}

\section{ABSTRACT}

Background: In order to present a model of normal personality first endeavor is to make the literal meaning of normal. Normal literally means according to the norms. An average is represented by this norm and it is dependent on a certain time and culture according to its definition. Renewed attention has recently been focused on the relationship between normal and abnormal personality functioning and distinctions between adaptive and pathological personality. In this study we have considered "mood disorder, Schizophrenia and conversion disorder as psychopaths." Therefore the study was conducted to know the difference between personality profile of normal and psychopaths of hill and plains. Methods: Study examined personality traits of 320 participants selected between 20-25 and 40-45 age groups purposively. The study was conducted on 80 normal, 80 bipolar mood disorders 80 schizophrenic and 80 conversion disorder patients. GHQ negative (score less than 3) subjects from the community formed the normal group for the study and psychopaths taken from Susheela Tiwari Forest Medical collage Haldwani, Uttrakhand, India. Bareilly mental hospital, Bareilly, India. Agra mental hospital, Agra, India, Nirwan Neuropsychiatric hospital, Lucknow, Uttarpradesh India. Sentence completion test (SCT) was administered on all the included subjects. Result: Significant difference found of mental conditions among 20-25 and 40-45 year male who belonging from hill area. Conclusion: Psychopathic female belonging from plain areas were very low 'social', 'ambitious' and 'confident' in comparison to Hill's female.

Keywords: Mental Health, Personality, Psychopaths, Hills Plains, SCT.

In order to present a model of normal personality our first endeavor is to make the literal meaning of normal. Normal literally means according to the norms. An average is represented by this norm and it is dependent on a certain time and culture according to its definition .Renewed attention has recently been focused on the relationship between normal and abnormal personality functioning and distinctions between adaptive and pathological personality have been

\footnotetext{
${ }^{1}$ Department of Psychology, Kumaun University Campus, Almora, Uttrakhand, India *Responding Author

(C) 2016, R Chandola; licensee IJIP. This is an Open Access Research distributed under the terms of the Creative Commons Attribution License (http://creativecommons.org/licenses/by/2.0), which permits unrestricted use, distribution, and reproduction in any Medium, provided the original work is properly cited.
} 


\section{The Personality Profile of Normal and Psychopaths of Hills and Plains: A Clinical Analysis}

increasingly questioned (Grove \& Tellegen, 1991; Strack \& Lorr, 1997) Many people have revaluated how normal personality relates to personality disorder and other types of behavioral pathologies (Krueger et al. 1996; Trull \& Sher 1994) the purpose of their study was to estimate the relative contribution of genetic and environmental influence to co-variation, between normal and abnormal personality traits using a sample of twins who were brought up at different places in different environment. It was sought to specify not also who by partitioning correlations among a comprehensive set of normal and abnormal traits into genetic and environmental components, from the introduction in DSMIII (American Psychiatric Association, 1980) a renewed focus on relationships between normal and abnormal personalities results in particularly on the Axis II personality disorder (Strack \& Lorr, 1994, 1997). The introduction Axis II initiated a number of debates in connections with the classification and diagnostic structure of personality disorder which not only focused on the use of categorical verses diagnostic schemes but also on the structure that those categories(Grove \& Tellegen 1991; Million \& Klerman, 1986).

Thought these issues do not stand fully resolved (Clark1999; Loranger, 1999) it is being increasingly consented upon the fact that abnormal personality is often modeled as being continuously distributed rather than being distributed categorically (Livesley, 1991; Widiger, 1993; Widiger \& Frances, 1994) and that the structure of abnormal personality is parallel to that of the normal Personality. (Costa \& Widiger 1994; Eyesenk, 1994; Schroeder; Wormworth and Livesly, 1992). Several studies have shown that there exists a correlation between the continuous measures of normal personality traits and personality disorders (Cloninger \& Svrakic 1994; Costs \& McCrae, 1990) as well as joint factor loadings of measures of normal and abnormal personalities (DiLalla Gottesman Carey and Vogler 1993 Schroeder et. al., 1994) these relationships have been demonstrated across a number of traits and have been limited only a few domains (Costa \& Widiger, 1994) and trait models (DiLalla, Gottesman, Corey \& Vogler 1993; Schroeder et. al., 1992) The agreement to that normal and for abnormal personalities are related to each other is not associated with an identical agreement as to why such a thing exists. In order to explain the relationship between normal and abnormal personality traits can influence or cause disorder and abnormal personality many model have been proposed which include the hypothesis that normal range personality traits can influence or cause disorder and abnormal personality traits can affect other normal range personality traits and also that normality and disorder exist in a spectrum each of which represent portions of a continuum (Widiger et. al. 1999). Many of these models have an empirical support and any of them could account for observed correlation between normal and abnormal personality traits to a certain extent (Widiger et.al. 1999).

Three key lines of research are responsible for the emergence of the idea that geographical difference exist in personality. Therefore most of these focus on social influence. The idea underlying it is that tradition, customs, life style and the daily practices the social norms which ultimate results in influencing the attitudes and behavior of people. Many studies of cross 
national psychological difference assume this as the basic. (Hofstead, 2001; Hofstead \& McCrae, 2004) Ecological influence or the idea that features of the physical environment influence the thought, feelings and behaviors of people is another line rather the second line on which research focuses. Geographical difference emerge from the historical prevalence of infectious diseases and there by result in the development which encourage cautiousness and risk aversion tendency so as to keep fit even in the unhealthy environment. (Murrary \& Schaller, 2013; Schaller, 2006; Schaller \& Murray, 2008).Climates and economic conditions also influence people's values and beliefs according to what an influential research program suggests (Van deVliert, 2009).

Lee et.al (1999, a, b) have written a very wide book on the international scenario of personality in cross- cultural perspective and cultural interaction. They have reported that personality traits are the representatives of human biology and they can be seen very clearly in the studies on heredity, parental influence, structural variance across culture and species and temporal disability. Here more stress has been given on biological base and equality of genes and environment. Maccoby (2000) has suggested that personality can be presented is a quadrangle way on its one side in genes and environment is on other side. Thus, it can be said that personality is comprised of genes and environment both. Moreover, behavior is not only the production of culture and personality but also it is situation based. Surprisingly, Gosling and John (1999) have recorded the relative significance of identified personality traits on animals. Pikar (1998) has also made critical comments on Shweders' ideas but Shweder (1991) has proposed that cultural psychology makes an interaction with culture and personality. He has described a detailed description of the relationship between culture and personality and relevance of cultural practices while generalizing the data. In this study we have considered "mood disorder, Schizophrenia and conversion disorder as psychopaths." Therefore the study was conducted to know the difference between personality profile of normal and psychopaths of hill and plains.

\section{METHOD}

\section{Participants:}

Three hundred twenty participants ranging between 20-25 and 40-45 years of age taken for the study.240 psychopaths hailed from four mental hospital of Uttarakhand and Uttarpradesh.GHQ negative (score less than 3) 80 participants from the community formed the normal group for the study. Sentence Completion Test was administered on all included subject.

\section{Tools:}

General Health Questionnaire-12 (GHQ-12): The 12-Item General Health Questionnaire (Jacob et al. 1997) is the most extensively used screening instrument for common mental disorders, in addition to being a more general measure of psychiatric well-being. 
The Personality Profile of Normal and Psychopaths of Hills and Plains: A Clinical Analysis

Sentence Completion Test: This test is developed by Dubey and Dubey (2006) and it is comprised of 50 incomplete sentence and the participants are instructed to complete every incomplete sentence by the first appearing thought of their mind The objective of this test to measure certain personality traits. An attempt has been made to measure three personality characteristics through the responses of the subjects. These traits are (1) Sociability, (2) Self Confidence, and (3) Ambitious. All the sentences are so framed that they lead to reveal the positive or negative aspect related to one of the traits.

\section{Procedure:}

Psychopaths like schizophrenic, bipolar and conversion disorder selected purposively from the indoor ward and outdoor from Susheela Tiwari Forest Medical, Collage, Haldwani, Uttrakhand, India. Bareilly mental hospital, Bareilly, India. Agra mental hospital, Agra, India, Nirwan Neuropsychiatric hospital, Lucknow, Uttarpradesh India. Informed consent was taken from patients and their available relatives, Interview conducted in a separate room associated with the ward to maintain confidentiality. Socio demographic detail filled before the interview with the help of patients, available relatives and with the help of case record file. GHQ negative (score less than 3) 80 participants from the community formed the normal group for the study. Sentence Completion Test was administered on all included subject.

\section{RESULTS}

Keeping in view the main objectives of the present study chi- square was apply to see the difference between hills and plains normal and psychopathic individual's personality traits.2x2 contingency table has been used for knowing the significant level, any cell was having an observed frequency less than 5, and then Yates correction was applied for the test significant. The result of the present study has been given below and consecutively discussed.

Table-1Socio-demographic characteristics of the participants there was two groups include in this study from the society. One group is normal and the other group is psychopathic group including four type of psychiatric disorder. Most of the participant in both groups was married. Occupation wise most of the participant (56.25\%) employee and the psychopathic group (70\%) were unemployed. Education level of the participant in normal group (40\%) found up to $12^{\text {th }}$ and the psychopathic group (70\%) found up to be $9^{\text {th }}$ standard.77.5\% normal participant belonging from urban area and 30\% psychopathic group belonging from rural area. Most of the participants in group one have middle economic status and the other counterpart has low economic status. 
The Personality Profile of Normal and Psychopaths of Hills and Plains: A Clinical Analysis

Table-1Showing other socio-demographic detail of normal and psychopathic group

\begin{tabular}{|c|c|c|c|c|c|c|c|c|c|}
\hline \multirow[t]{2}{*}{ Variable } & \multirow[t]{2}{*}{ Category } & \multicolumn{2}{|c|}{$\begin{array}{c}\text { Normal } \\
\mathbf{N}=\mathbf{8 0}\end{array}$} & \multicolumn{2}{|c|}{$\begin{array}{c}\text { Bipolar } \\
\text { mood dis. } \\
\mathbf{N}=80\end{array}$} & \multicolumn{2}{|c|}{$\begin{array}{l}\text { Schizophrenia } \\
\qquad \mathbf{N}=80\end{array}$} & \multicolumn{2}{|c|}{$\begin{array}{c}\text { Conversion } \\
\text { dis. } \\
\mathbf{N}=\mathbf{8 0}\end{array}$} \\
\hline & & $\mathbf{N}$ & $\%$ & $\mathbf{N}$ & $\%$ & $\mathbf{N}$ & $\%$ & $\mathbf{N}$ & $\%$ \\
\hline \multirow[t]{3}{*}{ Marital Status } & Married & 56 & $70 \%$ & 48 & $60 \%$ & 56 & $70 \%$ & 62 & $77.5 \%$ \\
\hline & Unmarried & 20 & $25 \%$ & 31 & $38.75 \%$ & 24 & $30 \%$ & 18 & $22.5 \%$ \\
\hline & Other & 4 & $5 \%$ & 1 & $1.25 \%$ & 0 & $0 \%$ & 0 & $0 \%$ \\
\hline \multirow[t]{3}{*}{ Occupation } & Unemployed & 23 & $28.75 \%$ & 42 & $52.5 \%$ & 44 & $55 \%$ & 56 & $70 \%$ \\
\hline & Employed & 45 & $56.25 \%$ & 18 & $22.55 \%$ & 15 & $18.75 \%$ & 12 & $15 \%$ \\
\hline & Semi skillful & 12 & $15 \%$ & 20 & $25 \%$ & 21 & $26.25 \%$ & 12 & $15 \%$ \\
\hline \multirow[t]{3}{*}{ Education } & Up to-9th & 17 & $21.25 \%$ & 23 & $28.75 \%$ & 56 & $70 \%$ & 54 & 67.5 \\
\hline & Up to 12 & 32 & $40 \%$ & 17 & $21.25 \%$ & 11 & $13.75 \%$ & 13 & 16.25 \\
\hline & Graduation & 31 & $38.75 \%$ & 40 & $50 \%$ & 13 & $16.25 \%$ & 13 & $16.25 \%$ \\
\hline \multirow[t]{2}{*}{ Residence } & Urban & 62 & $77.5 \%$ & 29 & $36.25 \%$ & 56 & $70 \%$ & 32 & $40 \%$ \\
\hline & Rural & 18 & $22.5 \%$ & 51 & $63.75 \%$ & 24 & $30 \%$ & 48 & $60 \%$ \\
\hline \multirow{3}{*}{$\begin{array}{l}\text { Income } \\
\text { (monthly) }\end{array}$} & Below-6000 & 36 & $45 \%$ & 49 & $61.25 \%$ & 46 & $57.5 \%$ & 41 & $51.25 \%$ \\
\hline & 6000 to 12000 & 33 & $41.25 \%$ & 9 & $11.25 \%$ & 11 & $13.75 \%$ & 11 & $13.75 \%$ \\
\hline & Above 12000 & 11 & 13.75 & 22 & $27.5 \%$ & 23 & $28.75 \%$ & 28 & $35 \%$ \\
\hline
\end{tabular}

Table-2 Gender wise residential setting and its effect on mental health

\begin{tabular}{|c|c|c|c|c|c|c|c|}
\hline \multirow{2}{*}{$\begin{array}{l}\text { Residential } \\
\text { Setting }\end{array}$} & \multirow[t]{2}{*}{ Sex } & \multirow{2}{*}{$\begin{array}{c}\text { Normal } \\
\mathrm{N}=\mathbf{8 0} \\
(25 \%)\end{array}$} & \multicolumn{4}{|c|}{ Psychopaths n=240 (75\%) } & \multirow{2}{*}{$\mathrm{X} 2$} \\
\hline & & & $\begin{array}{c}\text { Bipolar } \\
\text { mood dis. }\end{array}$ & Schizophrenia & $\begin{array}{c}\text { Conversion } \\
\text { dis. }\end{array}$ & Total & \\
\hline \multirow[t]{2}{*}{ Hills } & $\begin{array}{l}\text { Male } \\
n=74\end{array}$ & $23(31.08 \%)$ & $24(32.43 \%)$ & $15(20.27 \%)$ & $12(16.21 \%)$ & $51(21.25 \%)$ & \multirow{2}{*}{$\begin{array}{l}0.45 \\
\mathrm{df}=1 \\
\text { non } \\
\text { significant }\end{array}$} \\
\hline & $\begin{array}{c}\text { Female } \\
n=62\end{array}$ & $16(25.80 \%)$ & $16(25.80 \%)$ & $5(8.06 \%)$ & $25(40.32 \%)$ & $46(19.16 \%)$ & \\
\hline \multirow[t]{2}{*}{ Plains } & $\begin{array}{c}\text { Male } \\
\mathrm{n}=112\end{array}$ & $19(19.96 \%)$ & $24(21.42 \%)$ & $38(33.92 \%)$ & $31(27.67 \%)$ & $93(38.75 \%)$ & \multirow{2}{*}{$\begin{array}{l}4.67 \\
d f=1 \\
P<.05\end{array}$} \\
\hline & $\begin{array}{c}\text { Female } \\
\mathrm{N}=72\end{array}$ & $22(30.55 \%)$ & $16(22.22 \%)$ & $22(30.55 \%)$ & $12(16.66 \%)$ & $50(20.83 \%)$ & \\
\hline
\end{tabular}

Table-2 indicates that normal and psychopathic group belonging from hill and plain areas. Result indicate that male belonging from hill area having highly psychopathic trait (21.25\%) then female, the difference is statistically non significant and the other combination people belonging from plains area male having very high psychopathic traits (38.75\%) in comparison to female group this difference is statistically significant $(\mathrm{p}<.05)$.

(c) The International Journal of Indian Psychology, ISSN 2348-5396 (e)| ISSN: 2349-3429 (p) | 150 
The Personality Profile of Normal and Psychopaths of Hills and Plains: A Clinical Analysis

Table-3age wise distribution of residential setting and its effect on mental health

\begin{tabular}{|c|c|c|c|c|c|c|c|c|}
\hline \multirow[b]{2}{*}{$\begin{array}{l}\text { Residential } \\
\text { setting }\end{array}$} & \multirow[b]{2}{*}{ Sex } & \multirow[b]{2}{*}{ Age } & \multirow{2}{*}{$\begin{array}{l}\text { Normal } \\
\mathrm{N}=80(25 \%)\end{array}$} & \multicolumn{4}{|c|}{ Psychopaths n=240 (75\%) } & \multirow[t]{2}{*}{$\mathrm{X} 2$} \\
\hline & & & & $\begin{array}{l}\text { Bipolar } \\
\text { mood dis. }\end{array}$ & Schizophrenia & $\begin{array}{l}\text { Conversion } \\
\text { dis. }\end{array}$ & Total & \\
\hline \multirow[t]{4}{*}{ Hills } & \multirow{2}{*}{$\begin{array}{l}\text { Male } \\
\mathrm{n}=74\end{array}$} & $20-25$ & $9(12.16 \%)$ & $21(28.37 \%)$ & $6(8.10 \%)$ & $6(8.10 \%)$ & $33(13.75 \%)$ & \multirow{2}{*}{$\begin{array}{l}4.22 \\
\mathrm{P}<.05\end{array}$} \\
\hline & & $40-45$ & 14(18.91\%) & $3(4.05 \%)$ & $9(12.16 \%)$ & $6(8.10 \%)$ & $18(7.5 \%)$ & \\
\hline & \multirow{2}{*}{$\begin{array}{l}\text { Female } \\
\mathrm{n}=62\end{array}$} & $20-25$ & $5(8.06 \%)$ & $10(16.12 \%)$ & $4(6.45 \%)$ & $16(25.80 \%)$ & $30(12.5 \%)$ & \multirow{2}{*}{$\begin{array}{l}5.57 \\
\mathrm{P}<.05\end{array}$} \\
\hline & & $40-45$ & $11(17.74 \%)$ & $6(9.67 \%)$ & $1(1.61 \%)$ & $9(14.51 \%)$ & $16(6.66 \%)$ & \\
\hline \multirow[t]{4}{*}{ Plains } & \multirow{2}{*}{$\begin{array}{l}\text { Male } \\
\mathrm{N}=112\end{array}$} & $20-25$ & 12(10.71\%) & $14(12.5 \%)$ & 22(19.64\%) & $9(8.03 \%)$ & $45(18.75 \%)$ & \multirow{2}{*}{$\begin{array}{l}1.37 \\
\text { NS }\end{array}$} \\
\hline & & $40-45$ & $7(6.25 \%)$ & $10(8.92 \%)$ & $16(8.92 \%)$ & $22(19.64 \%)$ & $48(20 \%)$ & \\
\hline & \multirow{2}{*}{$\begin{array}{l}\text { Female } \\
\mathrm{N}=72\end{array}$} & $20-25$ & $18(25 \%)$ & $5(6.94 \%)$ & $9(12.5 \%)$ & $9(12.5 \%)$ & $23(9.58 \%)$ & \multirow{2}{*}{$\begin{array}{l}7.99 \\
\mathrm{P}<.01\end{array}$} \\
\hline & & $40-45$ & $4(5.55 \%)$ & $11(15.29 \%)$ & $13(18.05 \%)$ & $3(4.16 \%)$ & $27(11.25 \%)$ & \\
\hline
\end{tabular}

Table3 Shows sex and age group wise distribution of residential setting with their mental conditions. Significant difference $(\mathrm{p}<.05)$ was found in mental condition among 20-25 and 40-45 year male group who belonging from hill area, it was significantly high (13.75\%). Female (17.74\%) also statistically significant difference $(\mathrm{p}<.05)$ found in mental conditions between 2025 and 40-45 age among female group who belonging from hill area. Significantly difference $(\mathrm{p}<.01)$ was found in mental condition between20-25 and 40-45 age among female group who belonging from plain area. It was significantly high (25\%). In plains area insignificant difference was found in 20-25 and 40-45 male participants.

Table - 4 Sex wise comparison of personality traits of normal participants of hills and plains on the basis of sentence completion test.

\begin{tabular}{|c|c|c|c|}
\hline \multirow{3}{*}{$\begin{array}{l}\text { Gender according } \\
\text { to the residence }\end{array}$} & \multirow{2}{*}{\multicolumn{2}{|c|}{$\begin{array}{c}\text { Personality Traits } \\
\text { Sociability, Self confidence \& ambitiousness }\end{array}$}} & \multirow{3}{*}{$\mathrm{X} 2$} \\
\hline & & & \\
\hline & Very high & Very low & \\
\hline $\begin{array}{l}\text { Hill's male } \\
\qquad n=23\end{array}$ & 18(78.26\%) & $5(21.73 \%)$ & \multirow{2}{*}{\begin{tabular}{|l|}
0.05 df-1 \\
non \\
significantly \\
difference
\end{tabular}} \\
\hline $\begin{array}{c}\text { Plain's male } \\
n=19\end{array}$ & $13(68.42 \%)$ & $3(15.78 \%)$ & \\
\hline $\begin{array}{l}\text { Hill's female } \\
n=16\end{array}$ & $4(25 \%)$ & $12(75 \%)$ & \multirow[t]{2}{*}{$\begin{array}{l}10.23 \\
\mathrm{P}<.01\end{array}$} \\
\hline $\begin{array}{l}\text { Plain's female } \\
n=22\end{array}$ & $17(77.27 \%)$ & $5(22.72 \%)$ & \\
\hline
\end{tabular}

(C) The International Journal of Indian Psychology, ISSN 2348-5396 (e) | ISSN: 2349-3429 (p) | 151 
The Personality Profile of Normal and Psychopaths of Hills and Plains: A Clinical Analysis

Table-5Age wise comparison of-personality traits of normal participants of hills and plains on the basis of sentence completion test.

\begin{tabular}{|c|c|c|c|}
\hline \multirow{2}{*}{$\begin{array}{c}\text { Age according to } \\
\text { the residence }\end{array}$} & \multicolumn{2}{|c|}{ Personality Traits } & \multirow{2}{*}{ X2 } \\
\cline { 2 - 3 } & Sociability, Self confidence \& ambitiousness & \\
\cline { 2 - 3 } & Very high & $3(21.42 \%)$ & \\
\hline $\begin{array}{c}\text { Hill's 20-25 } \\
n=14\end{array}$ & $11(78.57 \%)$ & $17(58.62 \%)$ & \\
\hline $\begin{array}{c}\text { Plain's } 20-25 \\
n=29\end{array}$ & $12(41.37 \%)$ & $16(64 \%)$ & 0.26 \\
\hline $\begin{array}{c}\text { Hill's } 40-45 \\
n=25\end{array}$ & $9(36 \%)$ & $8(72.72 \%)$ & $\begin{array}{l}\text { Very low } \\
\text { non significantly } \\
\text { different. }\end{array}$ \\
\hline $\begin{array}{c}\text { Plain's 40-45 } \\
n=11\end{array}$ & $3(27.27 \%)$ & & \\
\hline
\end{tabular}

Table-4 Indicates the residential setting and gender relate with the personality traits. According to the table normal male participants belonging from plain area have high (68.42\%) level 'sociability', 'self confidence' and 'ambitiousness' insignificant difference was found between hills male and plains male on the personality traits. Significantly difference $(p<.01)$ was found between hills female and plain female on the personality traits. Plain's normal female (77.27\%) were highly 'social', 'ambitious' and 'confident' in comparison to other group.

Table-5 Indicates the residential setting and age relate with the personality traits. According to the table 20-25 year of age plain's participants very low (58.62\%) level of 'sociability', 'self confidence' and 'ambitiousness'. Significant difference $(\mathrm{p}<.05)$ was found between20-25 age group belonging from two different residential setting. There was insignificant difference was found between 40-45 age groups of hills and plain's participants and table indicate that 40-45 year hill's participants (64\%) very low 'social', 'ambitious' and 'confident' in comparison to other group.

Table -6 Sex wise comparisons of personality traits of psychopaths of hills and plains on the basis of sentence completion test.

\begin{tabular}{|c|c|c|c|}
\hline \multirow{3}{*}{$\begin{array}{l}\text { Gender according } \\
\text { to the residence }\end{array}$} & \multirow{2}{*}{\multicolumn{2}{|c|}{$\begin{array}{c}\text { Personality Traits } \\
\text { Sociability, Self confidence \& ambitiousness }\end{array}$}} & \multirow{3}{*}{$\mathrm{X} 2$} \\
\hline & & & \\
\hline & Very high & Very low & \\
\hline $\begin{array}{l}\text { Hill's male } \\
n=51\end{array}$ & 32 (62.74\%) & 19 (37.25\%) & \multirow{2}{*}{$\begin{array}{l}0 \\
\text { df-1 } \\
\text { Non significantly } \\
\text { different. }\end{array}$} \\
\hline $\begin{array}{l}\text { Plain’s male } \\
n=93\end{array}$ & $59(63.44 \%)$ & 34 (36.55\%) & \\
\hline $\begin{array}{l}\text { Hill's female } \\
n=46\end{array}$ & $16(34.78 \%)$ & 30 (65.21\%) & \multirow{2}{*}{$\begin{array}{l}1.34 \\
\text { Non significantly } \\
\text { different }\end{array}$} \\
\hline $\begin{array}{l}\text { Plain’s female } \\
n=50\end{array}$ & $12(24 \%)$ & 38 (76\%) & \\
\hline
\end{tabular}

(c) The International Journal of Indian Psychology, ISSN 2348-5396 (e)| ISSN: 2349-3429 (p) | 152 
The Personality Profile of Normal and Psychopaths of Hills and Plains: A Clinical Analysis

Table -7 Age wise comparison of personality traits of psychopaths of hills and plains on the basis of sentence completion test.

\begin{tabular}{|l|c|c|c|}
\hline \multirow{2}{*}{$\begin{array}{l}\text { Age according to } \\
\text { the residence }\end{array}$} & \multicolumn{2}{|c|}{ Personality Traits } & \multirow{2}{*}{ X2 } \\
\cline { 2 - 3 } & Sociability, Self confidence \& ambitiousness & \\
\cline { 2 - 3 } & Very high & Very low & $\begin{array}{c}6.86 \mathrm{df}-1 \\
\mathrm{P}<.01\end{array}$ \\
\hline $\begin{array}{l}\text { Hill's 20-25 } \\
\text { n=63 }\end{array}$ & $24(38.09 \%)$ & $39(61.90 \%)$ & \\
\hline $\begin{array}{l}\text { Plain's 20-25 } \\
\text { n=68 }\end{array}$ & $12(17.64 \%)$ & $56(82.35 \%)$ & $\begin{array}{l}0.66 \\
\text { Non significantly } \\
\text { different }\end{array}$ \\
\hline $\begin{array}{l}\text { Hill's 40-45 } \\
\text { n=34 }\end{array}$ & $29(85 \%)$ & $5(14.70 \%)$ & $16(21.33 \%)$ \\
\hline $\begin{array}{l}\text { Plain's 40-45 } \\
n=75\end{array}$ & $59(78.66 \%)$ & & \\
\hline
\end{tabular}

Table-6 Indicates the residential setting and gender relate with the personality traits. According to the table psychopathic male participants belonging from plain area have high (63.44\%) level 'sociability', 'self confidence' and 'ambitiousness' insignificant difference was found between hills psychopathic male and plains psychopathic male on the personality traits and insignificant difference was found hill's and plains female participants among personality traits. Table represents those (76\%) psychopathic female belonging from plain areas were very low 'social', 'ambitious' and 'confident' in comparison to other group.

Table-7 Indicates the residential setting and age relate with the personality traits. According to the table 20-25 year of age plain's psychopathic participants have very low (82.35\%) level of 'sociability', 'self confidence' and 'ambitiousness'. Significantly difference $(\mathrm{p}<.01)$ was found between20-25 age psychopathic group belonging from two different residential setting. There was insignificant difference was found between 40-45 age group of hills and plain's psychopathic participants and table indicate that 40-45 year hill's psychopathic participants (85\%) very high 'social', 'ambitious' and 'confident' in comparison to other group.

\section{DISCUSSION}

The study was conducted to explore the difference of personality between personality profile of normal and psychopaths of hill and plains. Result indicate that male belonging from hill area having highly psychopathic (21.25\%) then female, the difference is statistically non significant and the other combination people who belonging from plains area male had very high psychopathic morbidity (38.75\%) in comparison to female group this difference is statistically significant $(\mathrm{p}<.05)$. relationship between normal and abnormal personality functioning and distinctions between adaptive and pathological personality have been increasingly questioned (Grove \& Tellegen, 1991; Strack \& Lorr, 1997) Significantly difference $(\mathrm{p}<.01)$ was found in mental condition between 20-25 and 40-45 age among female group who belonging from plain

(C) The International Journal of Indian Psychology, ISSN 2348-5396 (e) | ISSN: 2349-3429 (p) | 153 
area. normal male participants belonging from plain area have high (68.42\%) level 'sociability', 'self confidence' and 'ambitiousness' insignificant difference was found between hills male and plains male on the personality traits. Climates and economic conditions also influence people's values and beliefs according to what an influential research program suggests (Van deVliert, 2009).There was insignificant difference was found between 40-45 age group of hills and plain's participants and table indicate that 40-45 year hill's participants (64\%) very low 'social', 'ambitious' and 'confident' in comparison to other group. psychopathic male participants belonging from plain area have high (63.44\%) level 'sociability', 'self-confidence' and 'ambitiousness', insignificant difference was found between hills psychopathic male and plains psychopathic male on the personality traits and insignificant difference was found hill's and plains female participants among personality traits. Significantly difference $(p<.01)$ was found between20-25 age psychopathic group belonging from two different residential setting.

\section{CONCLUSION}

Significantly difference was found in mental condition among 20-25 and 40-45 year male group who belonging from hill area. Normal male participants belonging from plain area have high (68.42\%) level 'sociability', 'self confidence' and 'ambitiousness' insignificant difference was found between hills male and plains male on the personality traits. Plain's normal female (77.27\%) were highly 'social', 'ambitious' and 'confident' in comparison to other group. Psychopathic female belonging from plain areas were very low social, ambitious and confident in comparison to other group.

\section{Acknowledgement:}

Authors are grateful to the Director and staff of Susheela Tiwari Forest Medical collage Haldwani, Uttrakhand, India. Bareilly mental hospital, Bareilly India. Agra mental hospital, Agra, U.P, India \& Nirwan Neuropsychiatric hospital Lucknow, Uttarpradesh India. For permission of data collection and study subjects study for their cooperativeness.

\section{Conflict of Interest:}

The paper is based on the Ph.D. work.

\section{REFERENCES}

American Psychiatric Association (1980).Diagnostic and statistical manual of mental disorder (3rd ed.).Washington, D.C.: Author

Clark, L. A. (1999). Dimensional approaches to personality disorder assessment and diagnosis. In C. R. Cloninger (Ed.), Personality and Psychopathology .Washington, DC: American Psychiatric Press. pp. 219-244

Cloninger, C. R., \& Svrakic, D. R. (1994). Differentiating normal and abnormal

Costa,P.T., \& McCrae, R. R. (1990).Personality disorders and the five-factor model of personality. Journal of Personality Disorders, 4, 362-371. 


\section{The Personality Profile of Normal and Psychopaths of Hills and Plains: A Clinical Analysis}

Costa, P. T.,\& Widiger, T. A. (Eds.).(1994).Personality disorders and the five-factor Cloninger, C. R., \& Svrakic, D. R. (1994). Differentiating normal and abnormal

DiLalla, D. L., Gottesman, I. I., Carey, G., and Vogler, G. P. (1993).Joint factor structure of the Multidimensional Personality Questionnaire and the MMPI in a psychiatric and high-risk sample. Psychological Assessment, 5, 207-215.

Dubey,L.N. and Dubay, A(2006)Sentence Completion Test, National Psychological corporation, Agra

Eysenck, H. J. (1994). Normality-abnormality and the three factor model of personality. In S. Strack \& M. Lorr (Eds.).Differentiating normal and abnormal personality). New York: Springer. pp. 3-25

Gosling SD \&JohnOP.(1999). Personality dimensions in non-human animals: a cross-species review. Curr. Dir. Psychol. Sci. 8:69-73

Grove, W. M., \& Tellegen, A. (1991).Problems in the classification of personality disorders. Journal of Personality Disorders, 5, 31-41.

Hofstede G (2001). Culture's consequences: Comparing values, behaviors, institutions, and organizations across nations (2nd ed.). Thousand Oaks, CA: Sage.

Hofstede G \& McCrae R R (2004).Personality and culture revisited: Linking traits and dimensions of culture. Cross-Cultural Research, 38, 52-88.

Jacob, K.S., Bhugra, D., Mann, A.H. (1997).The validation of the 12-item General Health Questionnaire among ethnic Indian women living in the United Kingdom. Psychological Medicine, 27(5): 1215-17.

Livesley, W. J. (1991). Classifying personality disorders: Ideal types, prototypes, or dimensions? Journal of Personality Disorders, 5, 52-59.

Loranger, A. W. (1999). Categorical approaches to assessment and diagnosis of personality disorders. In C. R. Cloninger (Ed.), Personality and psychopathology Washington, DC: American Psychiatric Press. pp. 201-217

Millon,T., \& Klerman, G. L. (1986). Contemporary directions in psychopathology: Toward the DSM-IV. New York: Guilford.

Murray D R \& Schaller M.(2013).Pathogen prevalence and geographical variation in traits and behavior. In Rentfrow P. J. (Ed.), Geographical psychology: Exploring the interaction of environment and behavior .pp. 51-7. Washington DC: American Psychological Association.

Schaller M (2006). Parasites, behavioral defenses, and the social psychological mechanisms through which cultures are evoked. Psychological Inquiry, 17, 96-137.

Schaller M \& Murray D R (2008).Pathogens, personality and culture: Disease prevalence predicts worldwide variability in sociosexuality, extraversion, and openness to experience. Journal of Personality and Social Psychology, 95, 212-221.

Schroeder, M. L., Wormworth, J. A. and Livesley, W. J. (1992).Dimensions of personality disorder and the five-factor model of personality. Psychological Assessment, 4, 47-53. 
The Personality Profile of Normal and Psychopaths of Hills and Plains: A Clinical Analysis

Strack, S., \& Lorr, M. (1997).Invited essay: The challenge of differentiating normal and disordered personality. Journal of Personality Disorders, 11, 105-122.

Strack, S., \& Lorr, M. (1997).Invited essay: The challenge of differentiating normal and disordered personality. Journal of Personality Disorders, 11, 105-122.

Trull, T. J., \& Sher, K. J.(1994). Relationship between the five-factor model of personality and axis I disorders in a nonclinical sample. Journal of Abnormal Psychology, 103, 350-360.

Krueger, R. F., Caspi, A., Moffit, T. E., Silva, P. A. and McGee, R. (1996).Personality traits are differentially linked to mental disorders: A multi trait multi diagnosis study of an adolescent birth cohort. Journal of Abnormal Psychology, 105, 299-312.

Lee Y-T, McCauley CR and Draguns JG, eds.(1999a).Personality and Person Perceptions Across Cultures. Mahwah, NJ: Erlbaum.

Lee Y-T, Mc Cauley CR, and Draguns JG. (1999b.)Why study personality in culture? See Lee et al. 1999a, pp. 3-22

Maccoby EE. (2000). Parenting and its effects on children: on reading and misreading behavior genetics. Annu. Rev. Psychol. 51:1-27

Piker S. (1998).Contributions of psychological anthropology. J. Cross-Cult. Psychol. 29:9-31

Shweder RA. ( 1991).Rethinking culture and personality theory. Thinking Through

Cultures: Expeditions in Cultural Psychology, ed. RA Schweder, pp. 269-312. Cambridge, MA: Harvard Univ. Press

Van de Vliert E (2009).Climate, affluence, and culture. Cambridge University Press. Widiger, T. A. (1993). The DSM-III-R categorical personality disorder diagnoses: A critique and an alternative. Psychological Inquiry, 4, 75-90.

Widiger, T. A., \& Frances, A. J. (1994).Toward a dimensional model of personality disorders. In P. T. Costa \& T. A. Widiger (Eds.),Personality disorders and the five-factor model of personality. Washington, DC: American Psychological Association. pp. 19-39

Widiger, T. A., Verheul, R. and van den Brink, W. (1999).Personality and psychopathology. In L. A. Pervin \& O. P. John (Eds.), Handbook of personality: Theory and research. 2nd ed., pp. 347-366. New York: Guilford.

How to cite this article: R Chandola (2016), The Personality Profile of Normal and Psychopaths of Hills and Plains: A Clinical Analysis, International Journal of Indian Psychology, Volume 3, Issue 4, No. 60, ISSN 2348-5396 (e), ISSN: 2349-3429 (p), DIP: 18.01.092/20160304, ISBN: 978-1-365-26308-8

(C) The International Journal of Indian Psychology, ISSN 2348-5396 (e)| ISSN: 2349-3429 (p) | 156 